\title{
Bovine Neoplasm
}

National Cancer Institute

\section{Source}

National Cancer Institute. Bovine Neoplasm. NCI Thesaurus. Code C134527.

A neoplasm that occurs in cattle. 